\title{
Instability indices and forecasting thunderstorms: the case of 30 April 2009
}

\author{
S. Tajbakhsh ${ }^{1}$, P. Ghafarian ${ }^{2}$, and F. Sahraian ${ }^{3}$ \\ ${ }^{1}$ Islamic Republic of Iran Meteorological Organization, Tehran, Iran \\ ${ }^{2}$ Department of Meteorology, Science and Research Branch, Islamic Azad University, Tehran, Iran \\ ${ }^{3}$ Atmospheric Science and Meteorological Research Center, Tehran, Iran \\ Correspondence to: P. Ghafarian (p_ghaffarian@ @otmail.com)
}

Received: 15 September 2010 - Revised: 27 November 2011 - Accepted: 16 December 2011 - Published: 17 February 2012

\begin{abstract}
In this paper, one meteorological case study for two Iranian airports are presented. Attempts have been made to study the predefined threshold amounts of some instability indices such as vertical velocity and relative humidity. Two important output variables from a numerical weather prediction model have been used to survey thunderstorms. The climatological state of thunder days in Iran has been determined to aid in choosing the airports for the case studies. The synoptic pattern, atmospheric thermodynamics and output from a numerical weather prediction model have been studied to evaluate the occurrence of storms and to verify the threshold instability indices that are based on Gordon and Albert (2000) and Miller (1972).

Using data from the Statistics and Data Center of the Iran Meteorological Organization, 195 synoptic stations were used to study the climatological pattern of thunderstorm days in Iran during a 15-yr period (1991-2005). Synoptic weather maps and thermodynamic diagrams have been drawn using data from synoptic stations and radiosonde data. A $15-\mathrm{km}$ resolution version of the WRF numerical model has been implemented for the Middle East region with the assistance of global data from University Corporation for Atmospheric Research (UCAR).
\end{abstract}

The Tabriz airport weather station has been selected for further study due to its high frequency of thunderstorms (more than 35 thunderstorm days per year) and the existence of an upper air station. Despite the fact that storms occur less often at the Tehran weather station, the station has been chosen as the second case study site due to its large amount of air traffic. Using these two case studies (Tehran at 00:00 UTC, 31 April 2009 and Tabriz at 12:00 UTC, 31 April 2009), the results of this research show that the threshold amounts of
$30{ }^{\circ} \mathrm{C}$ for $\mathrm{KI},-2{ }^{\circ} \mathrm{C}$ for $\mathrm{LI}$ and $-3{ }^{\circ} \mathrm{C}$ for SI suggests the occurrence and non-occurrence of thunderstorms at the Tehran and Tabriz stations, respectively. The WRF model output of vertical velocity and relative humidity are the two most important indices for examining storm occurrence, and they have a numerical threshold of $1 \mathrm{~m} \mathrm{~s}^{-1}$ and $80 \%$, respectively. These results are comparable to other studies that have examined thunderstorm occurrence.

\section{Introduction}

Since 1951, several techniques for predicting severe thunderstorms have been presented. Most of these methods are applicable for large-scale systems that are dominant in a given region (Fawbush et al., 1953; Miller, 1972). Doswell et al. (1981) and Maddox and Doswell (1982) have shown that these previously recommended methods were not suitable for thunderstorm forecasting because all severe thunderstorms develop due to mesoscale factors in an appropriate synoptic context. It is, therefore, necessary to study the behaviour of thunderstorms in mesoscale conditions. Moore et al. (2003) have investigated the environment of warmseason elevated thunderstorms associated with heavy rainfall over the central United States. Jacobs and Maat (2005) have presented numerical guidance methods for aiding the decision making related to aviation meteorological forecasts. Ramis et al. (2009) analysed a severe thunderstorm that occurred on 4 October 2007 in Mallorca, Spain from an observational viewpoint. It was found that the synoptic scenario was characterised by the advection of warm, moist air at low 
levels over the Balearic Islands and an upper-level trough over mainland Spain.

Vertical velocity, relative humidity and wind shear, which can be retrieved from Numerical Weather Prediction (NWP) model output, are very useful products for diagnosing the structure of thunderstorms. Colquhoun (1987, 1998) introduced the threshold values of these variables that are needed for thunderstorm occurrence, and he explained thunderstorm occurrence in terms of a decision tree and has shown that a vertical velocity larger than $0.5 \mathrm{~m} \mathrm{~s}^{-1}$ at $800 \mathrm{hPa}$ and a relative humidity larger than $75 \%$ are suitable threshold values for thunderstorm occurrence.

Systematic methods to diagnose the atmosphere's potential to produce severe convective weather can be of great help to forecasters. The most notable of these systematic approaches, the methods developed by Gordon and Albert (2000) and Miller (1972), applied in this paper. The checklists and reference guides developed by Gordon and Albert, and Miller are specifically designed to aid in the diagnosis of severe convective conditions.

Instability is a critical factor in the development of severe weather, and severe weather instability indices can be a useful tool when applied correctly to a given convective weather situation. Severe weather indices only indicate the potential for convection. A lifted index with a value of $0^{\circ} \mathrm{C}$ is sufficient for severe weather development only if the dynamics are very strong. When the lifting index is $-8^{\circ} \mathrm{C}$ or less, severe weather can occur with very weak upper-air support (Hales, 1996). Some of the most common indices that are applied in the study of thunderstorms are used in this paper: the K Index (George, 1960), the Lifted Index (Galway, 1956), the Showalter Stability Index (Showalter, 1953), Total Totals (Miller, 1972), the Severe Weather Threat Index (Miller, 1972), Convective Available Potential Energy (CAPE) and Convective Inhibition (CIN). A brief history of the application of these indices is described below.

In 1960, George introduced the relationship between KI and thunderstorm probability. According to his research, thunderstorms will occur with a $50 \%$ probability if the $\mathrm{KI}$ value is $26^{\circ} \mathrm{C}$ or more.

In 1956, Galway showed the critical values of LI for instability and argued that a negative LI indicates that the boundary layer is unstable with respect to the middle troposphere. This instability represents an environment in which convection can occur. Galway declared that LI values between -3 and $-5^{\circ} \mathrm{C}$ represent marginal instability. Showalter (1953) presented the threshold values of SI for thunderstorms, indicating that SI values from 0 to $-4{ }^{\circ} \mathrm{C}$ are suitable for moderate thunderstorms. The Total Totals and SWEAT indices were described by Miller in 1972. A SWEAT index between 300 and 400 indicates moderate thunderstorm activity, while a TT index between 50 and $55^{\circ} \mathrm{C}$ shows the possibility of severe thunderstorm activity. Generally, tornadoes are possible with thunderstorms when the SWEAT index reaches more than 400 (Henz, 2009). CAPE values less than
$300 \mathrm{~J} \mathrm{~kg}^{-1}$ show little or no convective potential, and CIN values greater than $200 \mathrm{~J} \mathrm{~kg}^{-1}$ are sufficient to prevent convection (Knutsvig, 2009). Haklander et al. (2003) examined 32 different indices and parameters, especially in the Netherlands, to gain statistical information on these parameters and compare their ability to forecast thunderstorms. Haklander and Delton (2003) have estimated the probability of a thunderstorm as a function of various thunderstorm predictors. They found that the thunderstorm probability depends on the following parameters (in order of importance): latent instability (especially near the surface), potential instability and conditional instability.

In the remaining sections of this paper, the synoptic conditions associated with thunderstorm events are reviewed for the two case studies. In addition, NWP model output and the threshold values of important thermodynamic instability indices for these two case studies are presented. Section 2 describes the synoptic and upper-air data that are necessary to draw the synoptic, thermodynamic and climatological charts. Also in this section, the WRF model is described in more detail. The climatology of thunderstorm days is used to describe the level of thunderstorm occurrence in Iran. This climatology has been analysed for a period of $15 \mathrm{yr}$, and the stations with the most and least thunderstorm days have been noted. The climatology of thunderstorm days in Iran is presented in Sect. 3. In Sect. 4, two case studies are analysed using threshold values from NWP model output and thermodynamic indices for thunderstorm forecasting, and the similarity with other studies is shown. The verification results are discussed in Sect. 5. Finally, a discussion of the potential for these indices to improve forecasts is given in Sect. 6, along with possibilities for future improvements.

\section{Data}

To identify the most appropriate indices for thunderstorm development at the two chosen airports in Iran, we needed to obtain more information about the climatology of thunderstorm days in the country. To better understand the thunderstorm climatology, we investigated the annual average number of thunder days that occurred in a $15-y r$ period. The primary data for this study were obtained from the archives of the I.R. of the Iran Meteorological Organization for the years 1990-2005 at 195 synoptic stations. The Surfer software programme and the Kriging interpolation method were used to analyse the data. The synoptic conditions were analysed using Global Forecast System (GFS) data with $1^{\circ}$ resolution in both latitude and longitude (http://nomads.ncdc.noaa.gov/data.php). The thermodynamic diagrams were completed with upper-air sounding data from the University of Wyoming (http://weather.uwyo. edu/upperair/sounding.html). Because of their importance in forecasting thunderstorms on the mesoscale, the vertical velocity, relative humidity and temperature fields from the 
Table 1. Parameterization of WRF model configuration.

Fully compressible no hydrostatic dynamics

15-km horizontal grid increment over Iran and 28 vertical levels

Radiative upper-boundary condition that mitigates noise resulting from reflecting gravity waves

Kain-Fritsch version 2 (Kain, 2004) cumulus parameterisation: month-long sensitivity tests showed this scheme produced the most realistic precipitation patterns and amounts compared to satellite-derived estimates

Lin et al. (1983) microphysics, which predicts the mixing ratio of four hydrometeor species (cloud droplets, cloud ice, rain, and snow)

Mellor-Yamada-Janjic PBL scheme (Janjic, 2002a,b). A set of multiday sensitivity experiments showed that this scheme is suitable over Iran.

Noah land surface model with four soil layers (Chen and Dudhia, 2001a, b)

Cloud effects on radiative transfer, Goddard scheme for shortwave and Rapid Radiative Transfer Model (Mlawer et al., 1997) for longwave

WRF regional model were used in this analysis. Table 1 shows the parameterisations that were chosen for producing the best behaviour of the atmosphere within the boundary layer and for maximising the numerical stability. Azadi et al. (2009) show that this parameterisation configuration provides good results over Iran.

\section{The climatology of thunderstorm days in Iran}

A thunderstorm occurs in response to synoptic-scale and mesoscale forcing. To develop a thunderstorm it usually needs warm and moist air at low levels, cool and dry air at upper levels and a synoptic-scale disturbance. Under these conditions, thunderstorm formation is probable. In fact, thunderstorm development requires large instability, vertical forcing, water vapour convergence at low levels and a high convective available energy; the synoptic-scale and mesoscale features described above favour these conditions. Several climatological studies have examined thunderstorms and their associated phenomena such as hail, heavy precipitation and severe winds. A study by Whiteman (2003) that considered the influence of orography on thunderstorms describes some of these climatological issues very well. Iran is located in a dry to semi-dry climate zone; therefore, moisture is generally not plentiful, and a large number of thunder days are not expected. During the warm season, the Azores high pressure dominates over Iran via the Mediterranean Sea. The Azores high covers the area south of the Alborz Mountains, and stable conditions cover all of Iran. During the cold season,

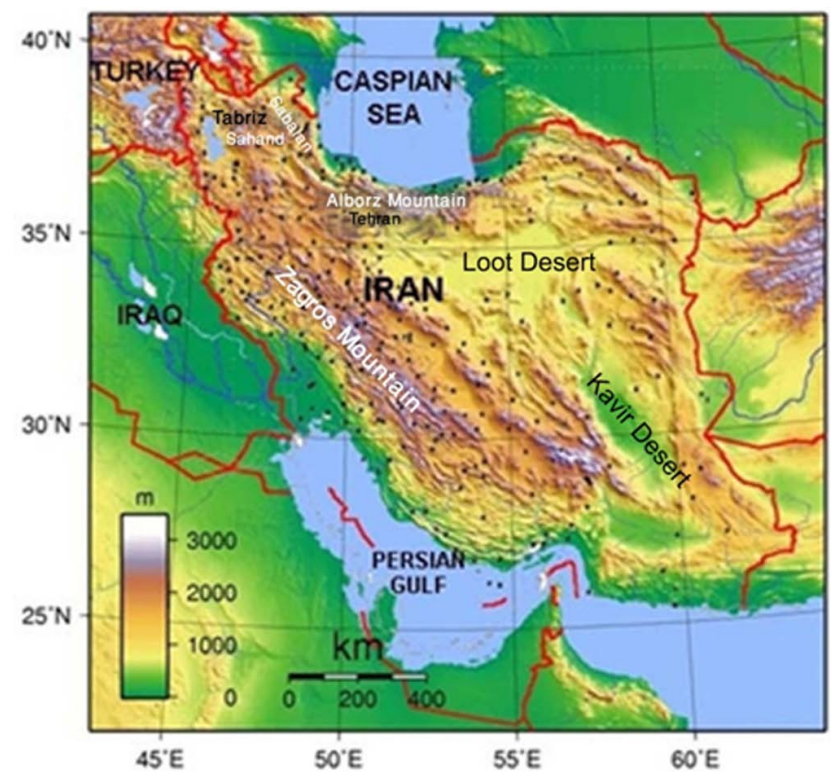

Fig. 1. Geographical position of Iran.

the westerlies are dominant over Iran. The westerlies steer Mediterranean disturbances toward Iran, causing instability and precipitation. Gheibi et al. (2003) presented temporal and spatial distributions of thunderstorms in Iran and showed that the annual distribution of thunderstorms is concentrated over the northwestern part of Iran. Thunderstorms usually occur during the spring and summer in Iran (Alijani, 2009), and for this reason, we selected our case studies in April. As noted earlier, the two airports (Tehran and Tabriz) are selected for further study due to their relatively large number of thunderstorm days and air traffic. Tehran is located on the southern slopes of the Alborz Mountains $\left(35.7^{\circ} \mathrm{N}, 51.4^{\circ} \mathrm{E}\right)$. The city has a dry climate with warm summers and relatively cold winters. Although the Alborz Mountains are far from the Tehran station (approximately $70 \mathrm{~km}$ ), the lifting effect of the mountains may intensify the vertical motion due to frontal convergence (Fig. 1). The Tabriz station $\left(38.6^{\circ} \mathrm{N}\right.$, $46.3^{\circ} \mathrm{E}$ ) is located in northwestern Iran. The Sabalan Mountains are located east of the city of Tabriz, while the Sahand Mountains are located south of the city (Fig. 1). Due to the orographic conditions, Tabriz has a cold and moist climate. Its topography provides favourable conditions for thunderstorm formation. Warm air rising and cold air sinking (convection) play a key role in the formation of severe thunderstorms. If the warm air at the surface is forced to rise, it will continue to rise because it is less dense than the surrounding air. In addition, it will transfer heat from the land surface to the upper levels of the atmosphere through the convection process. The orographic conditions cause thunderstorm formation by forcing air upward along the side of a mountain or large hill.

Figure 2 shows the monthly distribution of thunderstorm days for the stations at Tehran and Tabriz. Both of the 


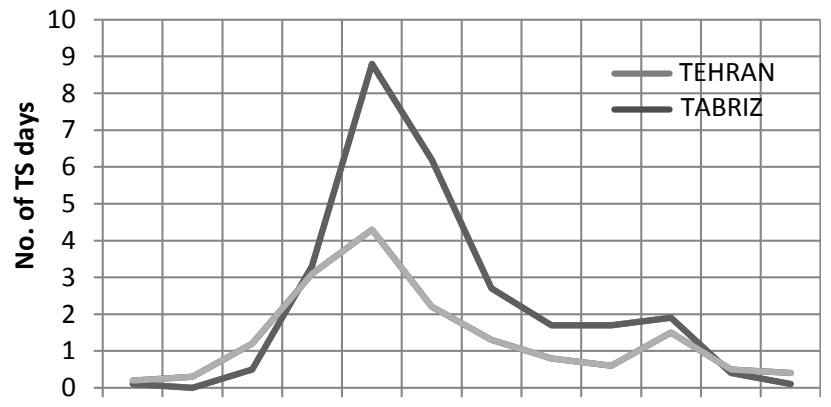

Jan. Feb. Mar. Apr. May Jun. Jul. Agu. Sep. Oct. Nov Dec.

Month

Fig. 2. Monthly average of $15 \mathrm{yr}$ period (1991-2005) thunder storm days for Tabriz (dark gray line) and Tehran (light gray line).

stations have similar distributions that confirm the study performed by Alijani (2009). Figure 2 shows that there is a maximum of thunderstorm days in May. Thunderstorm days decrease during the summer and reach a small peak in October. The number of thunderstorm days peaks at approximately 9 and 4.5 days for Tabriz and Tehran, respectively.

A climatological study of thunderstorm events can help to identify airport stations with more thunder days. The pattern of thunderstorm days in Iran is shown in Fig. 3, which shows that thunderstorms are not common in Iran. Additionally, Fig. 3 shows that the minimum number of stormy days occurs at the Jask station (one of Iran's southern islands in the Oman sea) with an average of 1.7 days annually and that the maximum number of stormy days occurs at the Makoo station in northwestern Iran with an average of 52 days annually. Examining Fig. 3 in the context of the climatological, meteorological and orographic conditions described above, a more detailed picture of Iran's thunderstorm climatology can be seen. For example, the maximum in thunderstorm days in northwestern Iran can be attributed to the orographic features found in that region. In contrast, the central, eastern and southeastern parts of Iran have the minimum number of thunderstorm days due to the presence of the Loot and Kavir deserts, which have very little moisture. The highest number of thunderstorm days occurs in the western half of the country, particularly in the northwestern part of the country where storms occur more than 20 days of the year. Stations with more than 30 thunder days, including Makoo, Safi-Abad Dezfool, Jolfa, Tabriz, Ahar, Sarab, Zanjan and Khoy, are mostly located in northwestern Iran. Stations with more than 45 stormy days are marked in Fig. 3. Additionally, more than 70 stations have less than 10 thunderstorm days annually. These stations are mostly located in the central and southeastern portions of the country. There are approximately 16 days per year with thunderstorms at the Tehran station in Tehran. It is clear that the prediction of thunderstorm days is not a priority at airports with either a relatively small number of thunderstorm days or a small number of flights. For
THUNDER DAY CLIMATOLOGY

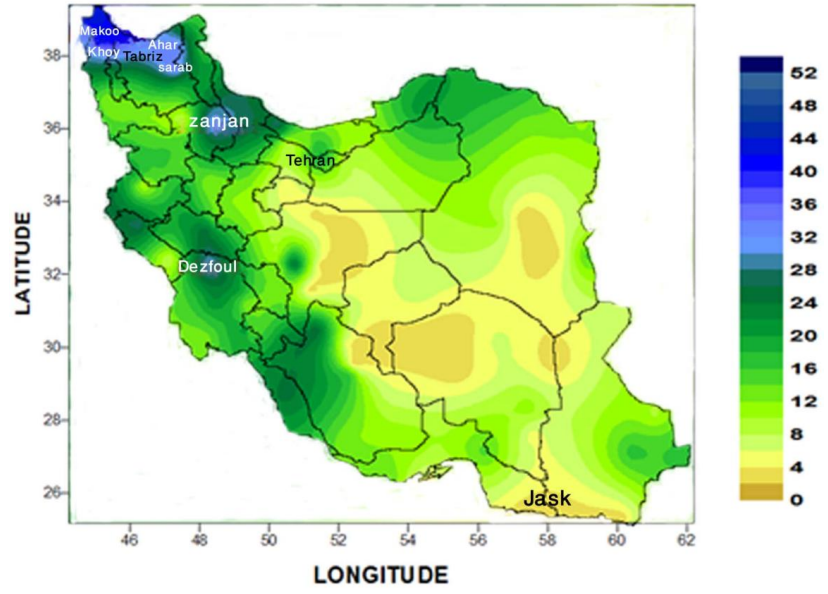

Fig. 3. Climatology of thunderstorm days (annual) in Iran during the period 1991 to 2005 .

this reason, we study some of the most important indicators for identifying and predicting storms at the Tabriz Airport because of its large number of days with thunderstorms and at the Tehran Airport because of its large number of flights.

\section{Case study of a thunderstorm event on 30 April 2009}

In considering the relationship between synoptic features and thunderstorm probability, the most important empirical indices to consider for severe weather conditions (instability indices) are KI, LI, SI, TT and SWEAT. These instability indices were calculated for the Tabriz and Tehran stations at 00:00 UTC, 30 April 2009 and 12:00 UTC, 30 April 2009, respectively. The Tabriz thunderstorm event was observed to be less than $8 \mathrm{~km}$ from the station. WRF model output of vertical velocity, relative humidity and temperature were used to predict the thunderstorms. Gordon and Albert (2000) present two checklists for identifying and forecasting thunderstorms using NWP model output and instability indices. These criteria are based on studies by various researchers that took place during and after the 1970s.

\subsection{Synoptic conditions}

On 30 April 2009, a cold front passed over the northern half of Iran and produced a moderate thunderstorm with rain showers in parts of Iran including the Tabriz airport station at 00:00 UTC and the Tehran airport station at 12:00 UTC. The synoptic patterns and thermodynamic diagrams for this system were reviewed in detail.

The surface map at 00:00 UTC shows cold air from Siberia intruding into the eastern part of Iran via a high pressure system and the gradual intensification of a trough of polar 


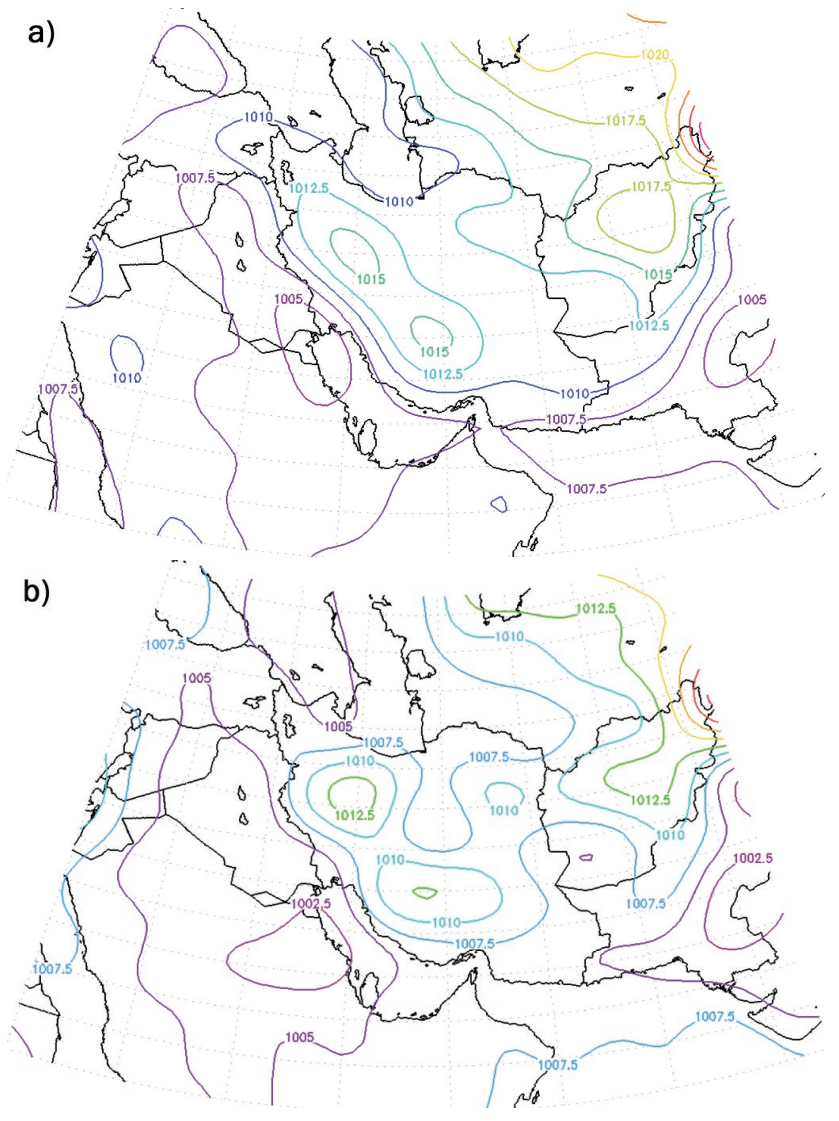

Fig. 4. (a) Surface chart include isobars with $2.5 \mathrm{mb}$ intervals on 30 April 2009 at 00:00 UTC. (b) Surface chart include isobars with $2.5 \mathrm{mb}$ intervals on 30 April 2009 at 12:00 UTC.

low pressure centre over the northwestern portion of Iran. A pressure gradient was present on the west coast of the Caspian Sea and on the southern slopes of the central Alborz Mountains while there was a centre of high pressure $(1015 \mathrm{hPa})$ in the western part of Iran (Fig. 4a). By 12:00 UTC, the pattern changed as the polar low deepened in the north and the Siberian high weakened (Fig. 4b). These conditions produced a pressure gradient in the southwestern portion of the Alborz Mountains. The surface pressure was $1011 \mathrm{hPa}(1009 \mathrm{hPa})$ at 00:00 UTC and $1009 \mathrm{hPa}$ $(1005 \mathrm{hPa})$ at $12: 00 \mathrm{UTC}$, while the dewpoint temperature was $\sim 10^{\circ} \mathrm{C}\left(6^{\circ} \mathrm{C}\right)$ at the Tehran (Tabriz) station at both times. At 00:00 UTC, the Tabriz station was affected by a ridge of high pressure, but the Tehran station was not yet affected. The 850-hPa chart shows an approaching low pressure trough in the northwestern strip of Iran at 00:00 UTC (Fig. 5a). Twelve hours later (Fig. 5b), the region was characterised by a thermal trough that extended from the northwest to the southern slopes of the central Alborz Mountains. This pattern provided appropriate conditions for warm advection in the mid-western parts of Iran and cold advection along the slopes of the Alborz Mountains. At $500 \mathrm{hPa}$, shallow

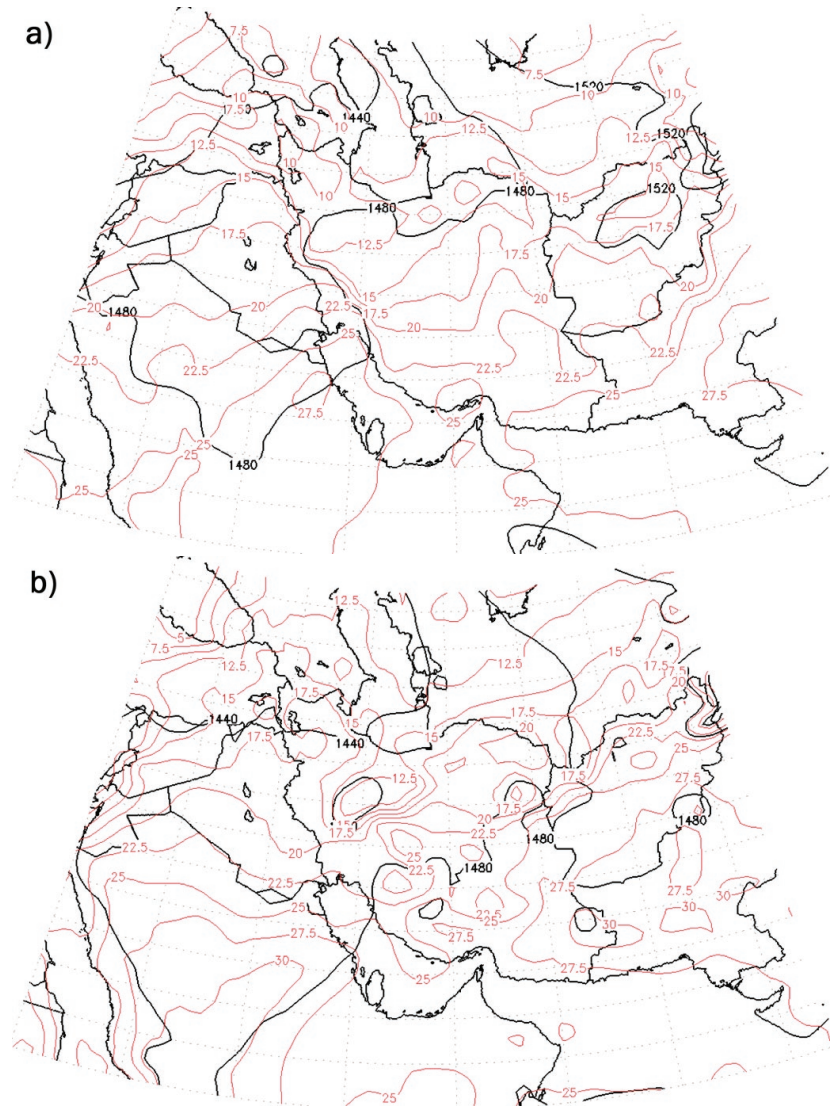

Fig. 5. (a) $850 \mathrm{hPa}$ chart include contours with $40 \mathrm{~m}$ and isotherms with $2.5^{\circ} \mathrm{C}$ intervals, respectively, on 30 April 2009 at 00:00 UTC. (b) $850 \mathrm{hPa}$ chart include contours with $40 \mathrm{~m}$ and isotherms with $2.5^{\circ} \mathrm{C}$ intervals, respectively, on 30 April 2009 at 12:00 UTC.

troughs intermittently passed across the northwestern and central Alborz Mountains at 00:00 and 12:00 UTC, respectively (Fig. 6a and b). One of these troughs, while passing over the central Alborz Mountains, produced a thunderstorm event in the Tehran area, which was reported at 12:00 UTC. In addition, the temperatures at $500 \mathrm{hPa}$ showed weak advection of cold air in the western half of Iran. At $300 \mathrm{hPa}$, there was no discernible strong jet streak at either 00:00 or 12:00 UTC. However, a $60-\mathrm{knot}$ wind speed $\left(30 \mathrm{~m} \mathrm{~s}^{-1}\right)$ was reported at the Rasht upper air station at 00:00 UTC (Fig. 7a), while only a 20 knot $\left(10 \mathrm{~m} \mathrm{~s}^{-1}\right)$ wind speed was recorded at the Tabriz station at this time. At the Tehran station, the wind speed values at 00:00 UTC and 12:00 UTC were 45 and 50 knots (22 and $25 \mathrm{~m} \mathrm{~s}^{-1}$ ), respectively. These values support the fact that no considerable velocity was reported for the jet stream that passed over Tehran. The Rasht and Tabriz stations only had sounding data at 12:00 UTC (Fig. 7b); therefore, the unstable conditions can only be qualitatively derived from synoptic conditions at the Tehran station at 12:00 UTC. 
a)

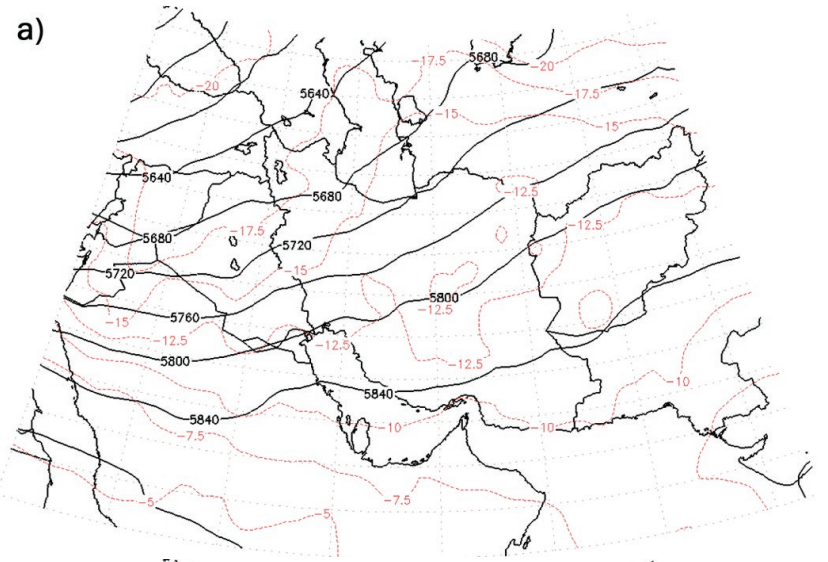

b)

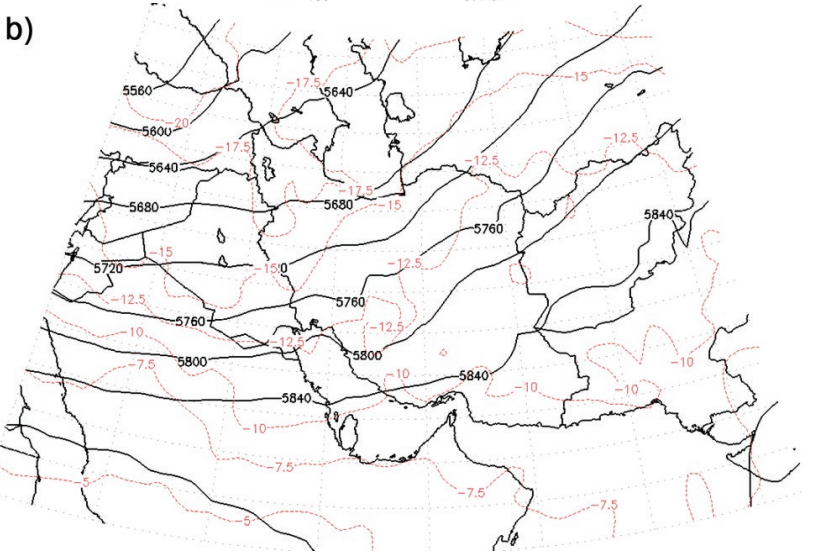

Fig. 6. (a) $500 \mathrm{hPa}$ chart include contours with $40 \mathrm{~m}$ and isotherms with $2.5^{\circ} \mathrm{C}$ intervals, respectively, on 30 April 2009 at 00:00 UTC. (b) $500 \mathrm{hPa}$ chart include contours with $40 \mathrm{~m}$ and isotherms with $2.5^{\circ} \mathrm{C}$ intervals, respectively, on 30 April 2009 at 12:00 UTC.

Table 2. Instability indices for Tehran and Tabriz stations on 30 April 2009.

\begin{tabular}{|c|c|c|c|}
\hline \multicolumn{2}{|c|}{$\begin{array}{c}\text { Tehran station } \\
30 \text { April } 2009 \text { at 12:00 UTC }\end{array}$} & \multicolumn{2}{|c|}{$\begin{array}{c}\text { Tabriz station } \\
30 \text { April } 2009 \text { at 00:00 UTC }\end{array}$} \\
\hline value & Index & value & Index \\
\hline-2.95 & LI & 2.29 & $\mathrm{Ll}$ \\
\hline-2.3 & SI & 2.17 & $\mathrm{SI}$ \\
\hline 36.8 & KI & 26.4 & $\mathrm{Kl}$ \\
\hline 54.6 & TT & 49 & TT \\
\hline 256 & SWEAT & 94.6 & SWEAT \\
\hline 313.6 & CAPE & - & CAPE \\
\hline-17 & CIN & - & CIN \\
\hline
\end{tabular}

\subsection{Thermodynamic diagrams}

To study the status of thunderstorm development more precisely, thermodynamic diagrams from the Tehran (12:00 UTC) and Tabriz (00:00 UTC) stations were reviewed. Atmospheric instability indices including
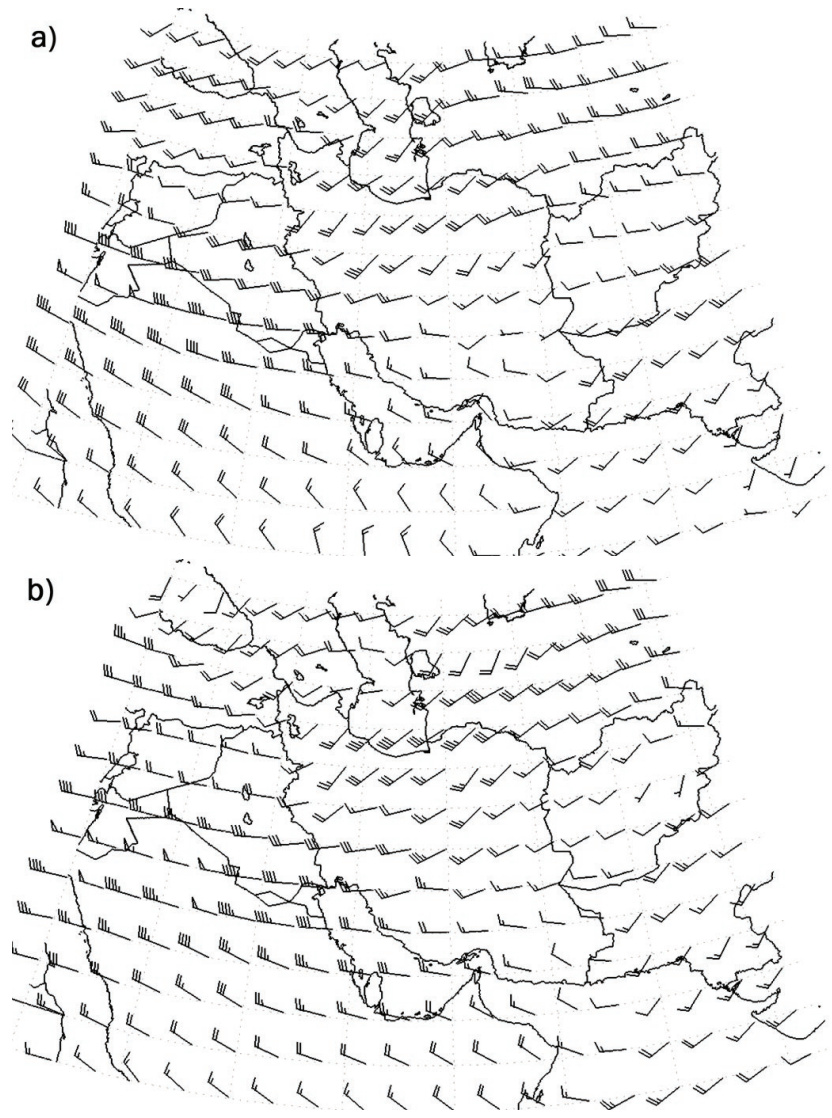

Fig. 7. (a) $300 \mathrm{hPa}$ chart on 30 April 2009 at 00:00 UTC. (b) $300 \mathrm{hPa}$ chart on 30 April 2009 at 12:00 UTC.

SI, LI, KI, SWEAT, TT, CAPE and CIN were calculated (Table 2). Because the Tabriz event did not occur exactly over the station at 00:00 UTC, the thermodynamic diagram shown in Fig. 8a does not contain considerable instability. There is no significant observed jet stream in the 200 to $300 \mathrm{hPa}$ layer, and the values of the instability indices indicate a non-storm environment, which is shown in Table 2. Due to the lack of significant instability, we did not calculate CAPE or CIN at this station and time. By 12:00 UTC, Tehran had experienced a relatively significant storm; hence, the dewpoint and temperature profiles indicate unstable conditions (strong convergence of the temperature and humidity profiles) and a 60 knot wind velocity in the 200 to $300 \mathrm{hPa}$ layer (Fig. 8b). Based on the criteria for thunderstorm occurrence from Galway (1956) and George (1960), the LI, $\mathrm{KI}$ and SI indices in Tehran at 12:00 UTC are acceptable for thunderstorm formation.

\subsection{NWP model output}

In this study, the WRF model was run and important model results were investigated. The most important of these results are the vertical velocity cross-section, temperature and 
Table 3. Gordon severe weather check list for Tehran and Tabriz stations on 30 March 2009.

\begin{tabular}{|c|c|c|c|}
\hline Severe weather parameters & Indicators & $\begin{array}{l}\text { Answer Y/N } \\
\text { (Tabriz) }\end{array}$ & $\begin{array}{l}\text { Answer } \\
\text { Y/N } \\
\text { (Tehran) }\end{array}$ \\
\hline \multirow{4}{*}{ Low level moisture and temperature } & Depth of low level moisture now (or expected) to be greater than $3000 \mathrm{ft}$ ? & $\sqrt{ }$ & $\sqrt{ }$ \\
\hline & Surface dew point $>14^{\circ} \mathrm{C}$ ? & - & - \\
\hline & Distinct low level surface temperature axis present? Location/Time? & & \\
\hline & $\begin{array}{l}\text { Will the } 850 \mathrm{hPa} \text { max temperature ridge be over or west of the } 850 \mathrm{hPa} \text { moisture } \\
\text { axis? }\end{array}$ & over & over \\
\hline \multirow{3}{*}{ Low level jet } & Is a low level jet present or expected to develop? Location/Time? & - & - \\
\hline & What is the Highest $850 \mathrm{hPa}$ jet speed & 14 knots & 11 knots \\
\hline & $850 \mathrm{hPa}$ moisture convergences expected? Location/Time? & - & - \\
\hline Upper Level Support & Will there be a $300 / 250 \mathrm{hPa}$ jet $>65$ knots? & - & - \\
\hline \multirow{3}{*}{ Lifting mechanism } & $\begin{array}{l}\text { Are any lifting mechanisms such as fronts or outflow boundaries present? List } \\
\text { them along with their location. }\end{array}$ & $\sqrt{ }$ & $\sqrt{ }$ \\
\hline & Will lifting mechanisms be able to overcome capping inversion? & $\sqrt{ }$ & $\sqrt{ }$ \\
\hline & $\mathrm{CIN}<50 \mathrm{~J} \mathrm{~kg}^{-1} ?$ & $\sqrt{ }$ & - \\
\hline \multirow{2}{*}{ Vertical wind shear } & Winds show significant veering $(0-3 \mathrm{~km}$ shear values $>35 \mathrm{kts})$ ? & - & - \\
\hline & $\begin{array}{l}\text { Is there (or will there be) speed shear }>25 \mathrm{kts} \text { and/or directional shear }>30 \\
\text { degrees between } 850 \text { and } 500 \mathrm{hPa} \text { ? }\end{array}$ & $\sqrt{ }$ & - \\
\hline \multirow{6}{*}{ Instability } & Is/will the Lifted Index be $<0$ ? & $\sqrt{ }$ & - \\
\hline & Is/will the K Index be $>30 ?$ & $\sqrt{ }$ & - \\
\hline & $\mathrm{C}$ Will CAPE $>800 \mathrm{~J} \mathrm{~kg}^{-1}$ ? & - & - \\
\hline & Will there be high mid level lapse rates $(700-500 \mathrm{hPa}) 6.5^{\circ} \mathrm{C} \mathrm{km}^{-1}$ ? & $\left(6.8^{\circ} \mathrm{C} \mathrm{Km}^{-1}\right)$ & \\
\hline & Will there be warm advection at $850 \mathrm{hPa}$ ? & $\sqrt{ }$ & - \\
\hline & Will a significant capping inversion remain in place? & - & $\sqrt{ }$ \\
\hline $700 \mathrm{mb}$ Dry Intrusion & $\begin{array}{l}\text { Is there or will there be a dry intrusion of air at or near the } 700 \mathrm{mb} \text { level? (Dew } \\
\text { point depression }>6^{\circ} \mathrm{C} \text { ) }\end{array}$ & - & - \\
\hline Upper Vertical Motion & Is large scale forcing indicated by model $Q$ vector and omega fields? & $\sqrt{ }$ & $\sqrt{ }$ \\
\hline Satellite Imagery/ Cloud Indicators & $\begin{array}{l}\text { Are there lines of cumulus or mid clouds (altocumulus castellanus-ACCAS) on } \\
\text { the morning satellite imagery? Is there significant mid level drying present on } \\
\text { water vapor imagery? }\end{array}$ & $\sqrt{ }$ & $\sqrt{ }$ \\
\hline \multirow{2}{*}{ Surface Pressure Falls } & Is there or will there be strong surface pressure falls? & $\sqrt{ }$ & $\sqrt{ }$ \\
\hline & $\begin{array}{l}\text { Will there be a corresponding pressure rise moving toward the fall area? (The } \\
\text { larger the absolute value of this rise-fall couplet, the larger the potential for } \\
\text { severe weather in the pressure fall area) }\end{array}$ & - & - \\
\hline
\end{tabular}

relative humidity patterns at the $700 \mathrm{hPa}$ level. These patterns were reviewed to identify characteristics of the thunderstorm events at 00:00 UTC on 30 April 2009 at the Tabriz station and 12:00 UTC at the Tehran station. Figure 9a represents the vertical velocity profile (VVP) at 00:00 UTC, and it shows a weak downdraft at $700 \mathrm{hPa}$ over the Tabriz station, while above this level, there is a weak updraft with VVP values of $0.3 \mathrm{~m} \mathrm{~s}^{-1}$. There is nearly zero VVP in the 700- to $800-\mathrm{hPa}$ layer. Figure 9a closely corresponds with the observed values by showing that at 00:00 UTC the thunderstorm was not active in Tabriz. Figure 9b shows a vertical cross-section of VVP. Regions of upward motion were observed in the 700 to $800 \mathrm{hPa}$ layer, and the values were between 0.5 and $1 \mathrm{~ms}^{-1}$, which are in agreement with the results from Colquhoun $(1987,1998)$. Figure 10 shows values of humidity and temperature at $700 \mathrm{hPa}$. Figure 10a (Fig. 10b) shows that the temperature at the Tabriz (Tehran) station is $\sim 2{ }^{\circ} \mathrm{C}\left(4^{\circ} \mathrm{C}\right)$ with a relative humidity of less than $60 \%(90 \%)$.

\subsection{The Gordon and Miller checklists}

The severity of the thunderstorm events in these two case studies was investigated using the data described above and the checklists provided by Gordon and Albert (2000) and Miller (1972). Table 3 is a checklist that can be used to 
a)

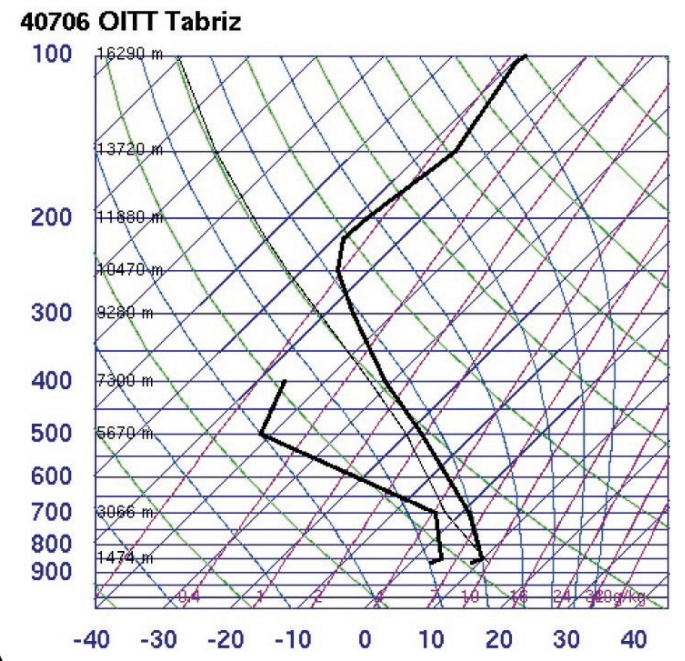

b)

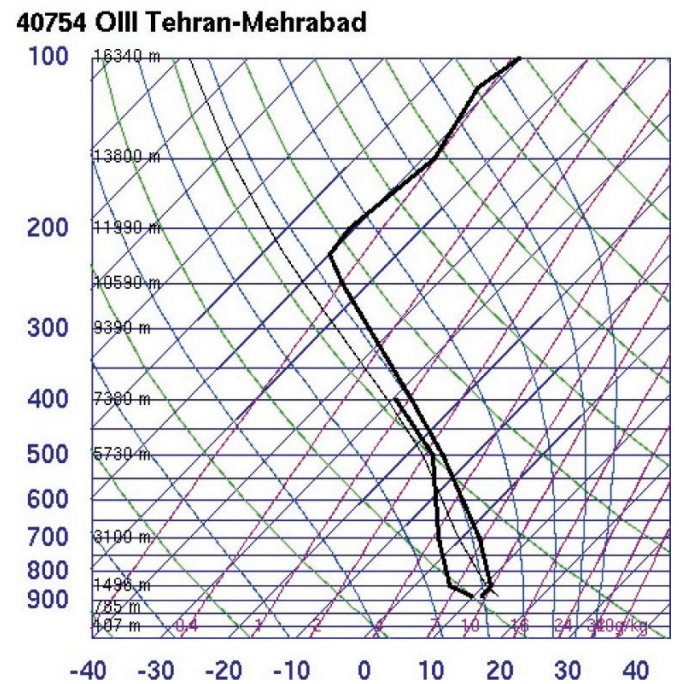

Fig. 8. (a) Thermodynamic diagrams on 30 April 2009 for Tabriz station at 00:00 UTC. (b) Thermodynamic diagrams on 30 April 2009 for Tehran at 12:00 UTC.

predict and identify thunderstorms and their severity. As the table shows, of the 10 important parameters used to forecast thunderstorms and severe weather, approximately 6 of these parameters show a positive response for the Tehran station. In fact, answers to the questions related to parameters 4, 5, 6, 8,9 and 10 are positive. Hence, based on the Gordon criteria, the event can be categorised into the organised thunderstorm group due to the number of positive responses. To evaluate the severity of the event at the Tehran station at 12:00 UTC on 30 April 2009, we used the Miller checklist. The surface pressure map (Fig. 4b) and the thermodynamic diagrams (Fig. 8b) show that the parameters in the Miller checklist (Table 3) have the following values at the Tehran station: the surface pressure is more than $1010 \mathrm{hPa}$, the dewpoint is greater than $13{ }^{\circ} \mathrm{C}$ and the change in the surface pressure within the
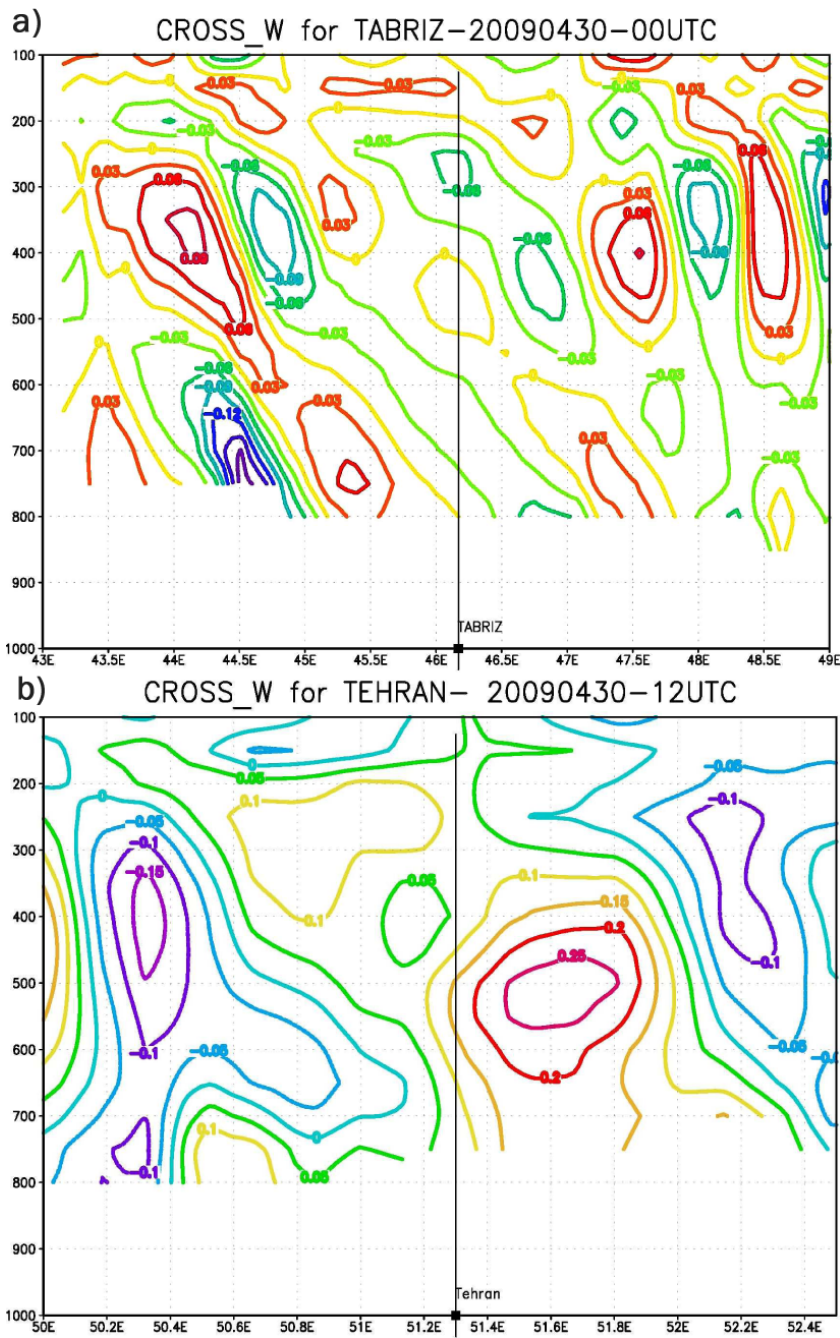

Fig. 9. (a) Vertical cross-section of vertical velocity $\left(\mathrm{m} \mathrm{s}^{-1}\right)$, on 30 April 2009 for Tabriz station. (b) Vertical cross-section of vertical velocity $\left(\mathrm{m} \mathrm{s}^{-1}\right)$, on 30 April 2009 for Tehran.

$12 \mathrm{~h}(00: 00$ UTC to 12:00 UTC) is between 0 and $-3 \mathrm{hPa}$. In addition, the temperature axis at $850 \mathrm{hPa}$ is located to the east of the moisture axis, and the dewpoint temperature is less than $8^{\circ} \mathrm{C}$. The maximum jet stream velocity is less than $66 \mathrm{kt}\left(33 \mathrm{~m} \mathrm{~s}^{-1}\right)$ in the 200- to $300-\mathrm{hPa}$ layer, and the mean relative humidity is $\sim 77 \%$. Using Table 2 , we can determine the instability indices: $\mathrm{TT}=54.6^{\circ} \mathrm{C}, \mathrm{LI}=-3{ }^{\circ} \mathrm{C}$, $\mathrm{CAPE}=314 \mathrm{~J} \mathrm{Kg}^{-1}$, SWEAT $=256$ and $\mathrm{SI}=-2{ }^{\circ} \mathrm{C}$. Based on Table 3, most of the Miller checklist parameters indicate a moderate to severe thunderstorm event. The same analysis was performed for the Tabriz station. The results are shown in Table 3. Using radiosonde data from the Tabriz station (Fig. 7a), the data show that only 2 of the parameters ( 1 and 3 ) were positive, while the remaining 8 parameters were negative. This result means that the thunderstorm is not active and, according to Gordon, it will not be necessary to proceed to the Miller checklist because there are less than 6 positive answers in the Gordon checklist. 


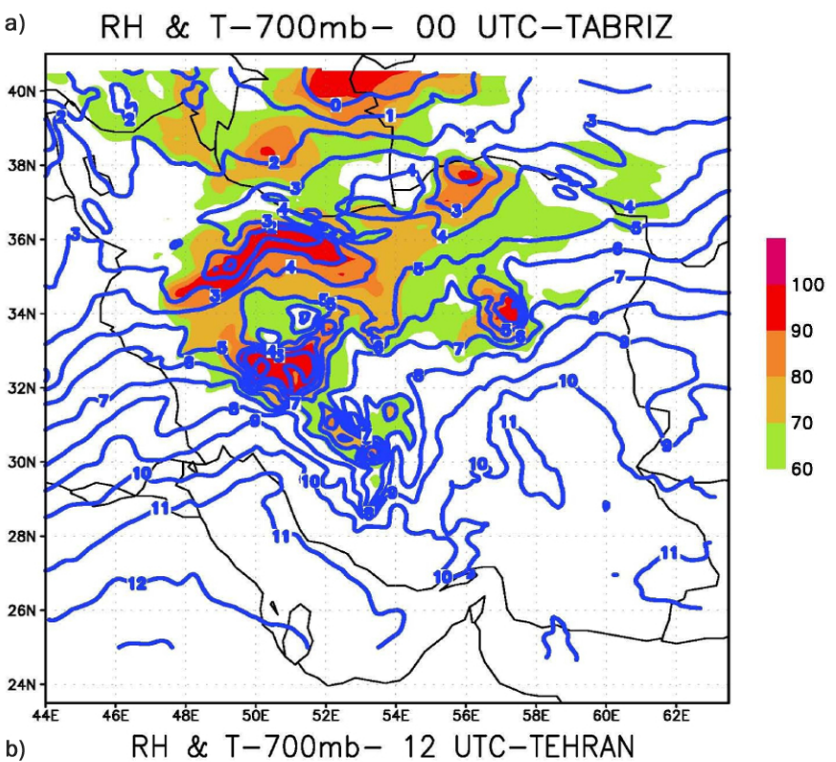

b)

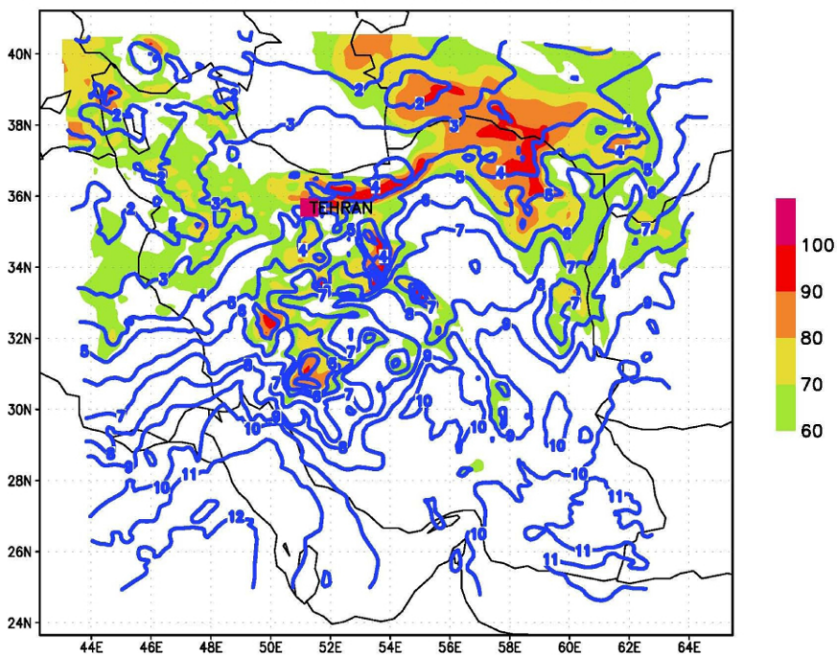

Fig. 10. (a) Temperature and relative humidity at $700 \mathrm{hPa}$ on 30 April 2009 for Tabriz station. (b) Temperature and relative humidity at $700 \mathrm{hPa}$ on 30 April 2009 for Tehran.

\section{Discussion}

In our case studies, the synoptic charts present a weak pressure gradient over Tehran and Tabriz. Pressure gradients play a main role in providing convergence and updrafts. Convergence is one of the trigger mechanisms needed for providing upward motions, which are part of the foundation for thunderstorm formation. Even a very moist atmosphere cannot produce strong thunderstorm development without a convergence mechanism. In our cases, the role of the orographic features clearly aids in preparing conditions for ascent. For example, despite the weak pressure gradient, the topographic conditions helped to form stormy weather at the Tehran and Tabriz airports. The Sahand and Sabalan Mountains around the city of Tabriz and the Alborz Mountains north of Tehran (Fig. 1) have produced lifting for thunderstorm formation.
The climatology of thunderstorm days in Iran shows that statistically only a few stations have more than 50 days with thunderstorms and that a slightly larger number of stations have more than 30 days annually with thunderstorms. Because of this climatology, the country can be considered as a region with a limited number of thunderstorm events. Despite the fact that most of these stations are not airport stations, the thunderstorm events are still considered important because of the risks to flight operations associated with thunderstorms. Therefore, we chose to investigate two important regions for our case study: the Tehran station due to its high number of flights (more than 400 aircraft landing and taking off daily) and the Tabriz station due to its relatively high number of thunder days. The synoptic patterns in this case study indicate relatively favourable conditions for instability in Tehran. A surface pressure gradient, temperature advection at $850 \mathrm{hPa}$ and the presence of cold air in the upper levels provided suitable conditions for instability in the lower layers of the atmosphere. The thermodynamic diagrams for the Tabriz station show a shallow radiation inversion at 00:00 UTC that is indicative of stability at very low levels. There was also no considerable moisture at the station. In contrast, at 12:00 UTC in the Tehran region, no lower-level temperature inversion was observed, and the moisture content was higher than at the Tabriz station. Because the moisture content that is observed at Tehran is still not significantly large, the thunderstorm intensity was moderate to light. Two of the most important causes of severe weather conditions are high humidity in the lower levels and rising air; hence, these two parameters are the most important NWP model output variables for thunderstorm forecasting. In our study, humidity of more than $90 \%$ and a vertical velocity equal to $1 \mathrm{~m} \mathrm{~s}^{-1}$ at $700 \mathrm{hPa}$ produced a relatively severe thunderstorm in Tehran. Atmospheric instability indices including KI and SI confirmed a weak to moderate thunderstorm in Tehran, while no thunderstorm was forecast for Tabriz. These results are verified with observations. Haklander and Delden (2003) determined the threshold values for important instability indices for the Netherlands using statistical methods and 32 different parameters to determine the ability of those threshold values to forecast thunderstorms. They found the following threshold values: $\mathrm{KI} \geq 21^{\circ} \mathrm{C}$, LIsfc $\leq 1.6^{\circ} \mathrm{C}$, SHOW $\leq 4.2^{\circ} \mathrm{C}, \mathrm{TT} \geq 46.7^{\circ} \mathrm{C}$, $\mathrm{CAPE} \geq 173 \mathrm{~J} \mathrm{Kg}^{-1}$ and SWEAT $\geq 134$. A comparison of the values of these indices with the two case studies in Iran (Table 3) confirms the occurrence and non-occurrence of thunderstorms for the Tehran and Tabriz stations, respectively.

Applying the Gordon checklist to the Tehran case study, it was found that the answers to 6 of the 10 questions were positive. This result indicates that the event is categorised in the organised thunderstorm class. To determine the severity of the thunderstorm event, the Miller checklist was used to examine certain atmospheric parameters associated with the event (Table 4). The table shows that the Tehran case may 
Table 4. Miller severe weather checklist.

\begin{tabular}{|c|c|c|c|c|}
\hline No. & Parameter & Weak & Moderate & Strong \\
\hline 1 & Surface Pressure & $>1010 \mathrm{mb}$ & 1010 to $1005 \mathrm{mb}$ & $<1005 \mathrm{mb}$ \\
\hline 2 & Surface Dew Point & $<55^{\circ} \mathrm{F}$ & $55-64^{\circ} \mathrm{F}$ & $65^{\circ}$ \\
\hline 3 & $12 \mathrm{~h}$ Surface Pres Change & 0 to -3 & -4 to -7 & -8 \\
\hline 4 & $850 \mathrm{mb}$ Temp Axis & East of Moist Axis & Over Moist Axis & West of Moist Axis \\
\hline 5 & $850 \mathrm{mb}$ Jet & $<25 \mathrm{kts}$ & $25-35 \mathrm{kts}$ & $>35 \mathrm{kts}$ \\
\hline 6 & $850 \mathrm{mb}$ Dew Point & $8^{\circ} \mathrm{C}$ & $8-12{ }^{\circ} \mathrm{C}$ & $>12^{\circ} \mathrm{C}$ \\
\hline 7 & $700 \mathrm{mb}$ Dry Intrusion & N/A or Weak $700 \mathrm{mb}$ winds & $\begin{array}{l}\text { Winds from dry to moist intrude } \\
\text { at }<40^{\circ} \text { and are } 15 \mathrm{kts}\end{array}$ & $\begin{array}{l}\text { Winds intrude at an } 40^{\circ} \text { and are } \\
25 \mathrm{kts}\end{array}$ \\
\hline 8 & $\begin{array}{l}700 \mathrm{mb} \text { Temp No Change } \\
\text { Line }\end{array}$ & Winds cross line $20^{\circ}$ & Winds cross line $>20^{\circ}$ and $40^{\circ}$ & Winds cross line $>40^{\circ}$ \\
\hline 9 & $500 \mathrm{mb}$ Height Change & $<30 \mathrm{~m}$ & 30 and $59 \mathrm{~m}$ & $60 \mathrm{~m}$ \\
\hline 10 & $500 \mathrm{mb}$ Wind Speed & $35 \mathrm{kts}$ & $36-49 \mathrm{kts}$ & $50 \mathrm{kts}$ \\
\hline 11 & $500 \mathrm{mb}$ Vorticity Advection & Neutral or NVA & $\begin{array}{l}\text { PVA-Contours Cross Vorticity } \\
\text { Pattern } 30^{\circ}\end{array}$ & $\begin{array}{l}\text { PVA-Contours Cross Vorticity } \\
\text { Pattern }>30^{\circ}\end{array}$ \\
\hline 12 & $\begin{array}{l}850-500 \mathrm{mb} \text { Wind Shear } \\
\text { (a) Speed Shear } \\
\text { (b) Directional Shear }\end{array}$ & $\begin{array}{l}15-25 \mathrm{kts} \\
20-30^{\circ}\end{array}$ & $\begin{array}{l}26-35 \mathrm{kts} \\
30-60^{\circ}\end{array}$ & $\begin{array}{l}>35 \mathrm{kts} \\
>60^{\circ}\end{array}$ \\
\hline 13 & $300-200 \mathrm{mb}$ Jet & $65 \mathrm{kts}$ & $66-85 \mathrm{kts}$ & $>85 \mathrm{kts}$ \\
\hline 14 & Mean R.H. & $70-80 \%$ or $40-50 \%$ & $50-70 \%$ & $50-70 \%$ \\
\hline 15 & TT & $<50$ & $50-55$ & $>55$ \\
\hline 16 & LI & $>-2$ & -3 to -5 & -6 \\
\hline 17 & CAPE & $800-1500 \mathrm{~J} \mathrm{~kg}^{-1}$ & $1500-2500 \mathrm{~J} \mathrm{~kg}^{-1}$ & $>2500 \mathrm{~J} \mathrm{~kg}^{-1}$ \\
\hline 18 & SWEAT & $<300$ & $300-500$ & $>500$ \\
\hline 19 & WBZ & $\begin{array}{l}>11000 \mathrm{ft} \\
<5000 \mathrm{ft}\end{array}$ & $\begin{array}{l}9000-11000 \mathrm{ft} \\
5000-7000 \mathrm{ft}\end{array}$ & $7000-9000 \mathrm{ft}$ \\
\hline 20 & Helicity $(0-3 \mathrm{~km})$ & $150-300 \mathrm{~m}^{2} \mathrm{~s}^{-2}$ & $300-450 \mathrm{~m}^{2} \mathrm{~s}^{-2}$ & $>450 \mathrm{~m}^{2} \mathrm{~s}^{-2}$ \\
\hline 21 & SI & -1 to +2 & -1 to -3 & $<-3$ \\
\hline
\end{tabular}

be classified as a weak thunderstorm. In contrast, the event that occurred at the Tabriz station was not placed into the organised class of thunderstorms found in the Gordon checklist. Therefore, according to the Miller checklist, there was no need to review the severity of the thunderstorm because it was very weak. In fact, the Gordon and Miller checklists provide synoptic and mesoscale methods, respectively, to study thunderstorm events using specific criteria that consider all related parameters. If NWP models were configured to answer the questions on the checklists, they could be considered a good guide for forecasting thunderstorms and determining their severity.

\section{Conclusions}

Atmospheric instability is a critical factor in determining if thunderstorm development will commence. Certain parameters, including vertical motion and low-level moisture content, are used to review and evaluate the atmospheric instabilities that may lead to thunderstorm development. In addition, climatological information concerning storm occurrence can aid in statistically determining the important indicators and phenomena that create these storms. The climatology of thunderstorm days in Iran shows that some meteorological stations in the western portion of the country have thunderstorms on more than 30 days a year. This study showed that KI, LI and SI are appropriate indicators of instability. We determined suitable threshold values for thunderstorms that occurred at the Tehran and Tabriz airport stations: $30^{\circ} \mathrm{C}$ for $\mathrm{KI},-2{ }^{\circ} \mathrm{C}$ for $\mathrm{LI}$ and $-3^{\circ} \mathrm{C}$ for SI are indicators of moderate to severe thunderstorms. Humidity and vertical velocity from NWP models are the most important variables for identifying atmospheric instability and can be considered proper tools to support thunderstorm forecasting. The threshold values of relative humidity and vertical velocity are $80 \%$ and $1 \mathrm{~m} \mathrm{~s}^{-1}$, respectively. Additional tools, such as the Gordon and Miller checklists, can help and guide weather forecasters to predict thunderstorms. Although the threshold 
values in these checklists have already been determined for North America, we found that using these checklists can also be a suitable approach for forecasting thunderstorms in Iran. Certainly, for these checklists to be used in an operational forecasting environment, additional statistical analyses will need to be performed that include local and regional factors such as terrain and elevation for the particular location of interest.

Acknowledgements. The authors are grateful to the Editor and the anonymous reviewers for the precious remarks and comments which led to improve the initial version of this paper.

Edited by: M.-C. Llasat

Reviewed by: three anonymous referees

\section{References}

Alijani, B.: Iran Climate, Payam nour pres., Iran, 2009.

Azadi, M., Kaffash, N., and Abdollahzadeh, I.: Probabilistic precipitation forecasting using ensemble forecasting system over Iran., 8th Conference on Numerical Weather Prediction, Atmospheric Science and Meteorological Research Center (ASMERC), Tehran, Iran, 2009.

Chen, F. and Dudhia, J.: Coupling an advanced land-surface/ hydrology model with the Penn State/NCAR MM5 modeling system, Part I: Model implementation and sensitivity. Mon. Weather Rev., 129, 569-585, 2001a.

Chen, F. and Dudhia, J.: Coupling an advanced landsurface/hydrology model with the Penn State/NCAR MM5 modeling system, Part II: Model validation, Mon. Weather Rev., 129, 587-604, 2001b.

Colquhoun, J. R.: A decision tree method of forecasting thunderstorms, severe thunderstorms and tornadoes, Weather Forecast., 2, 337-345, 1987.

Colquhoun, J. R.: A decision tree method of forecasting thunderstorms, severe thunderstorms and tornadoes revisited, Proc. Fifth Australian Severe Thunderstorm Conf., Avoca Beach, New South Wales, Australia, Australian Bureau of Meteorology, 135141, 1998.

Doswell III, C. A., Lemon, L. R., and Maddox, R. A.: Forecaster training - a review and analysis, Bull. Amer. Meteor. Soc., 62, 983-988, 1981.

Easterling, D. R.: Climatological patterns of thunderstorm activity in south-eastern USA, Int. J. Climatol., 11, 213-221, 2007.

Fawbush, E. J. and Miller, R. C.: A method of forecasting hailstone size at the earth's surface, Bull. Amer. Meteor. Soc., 34, 235$244,1953$.

Galway, J. G.: The lifted index as a predictor of latent instability, Bull. Amer. Meteor. Soc., 37, 518-529, 1956.

George, J. J.: Weather forecasting for aeronautics, Academic press, 673 pp., 1960.
Gheiby, A., Sen, N., Puranik, D., and Karekar, R.: Thunderstorm identification from AMSU-B data using an artificial neural network, Meteorol. Appl., 10, 329-336, 2003.

Gordon, J. and Albert, D.: A comprehensive severe weather forecast checklist and reference guide, Noaa technical service publication, TSp 10, NWS central region, 2000.

Hales, E.: Severe weather forecasting, Personal SPC notes, Severe Weather Forecast., 1996.

Haklander, A. J. and Delton, A. Van.:Thunderstorm predictors and their forecast skill for the Netherlands, Atmos. Res., 67-68, 273299, 2003.

Henz, D.: Soundings and Adiabatic Diagrams for Severe Weather Prediction and Analysis, AOS, 453, 2009.

Jacobs, A. J. M. and Maat, N.: Numerical guidance methods for decision support in aviation meteorological forecasting, Weather Forecast., 20, 82-100, 2005.

Janjic, Z. I.: A Nonhydrostatic Model Based on a New Approach, EGS XVIII, Nice France, 21-26 April 2002, 2002a.

Janjic, Z. I.: Nonsingular Implementation of the Mellor-Yamada Level 2.5 Scheme in the NCEP Meso model, NCEP Office Note, 437, 61 pp., 2002 b.

Kain, J. S.: The Kain-Fritsch convective parameterization: An update, J. Appl. Meteor., 43, 170-181, 2004.

Knutsvig, R.: "Severe Weather Indices", University of North Dakota, available at: http://www.geocities.com/weatherguyry/ swx2.html, 2009.

Lin, Y.-L., Farley, R. D., and Orville, H. D.: Bulk parameterization of the snow field in a cloud model, J. Clim. Appl. Meteor., 22, 1065-1092, 1983.

Maddox, R. A. and Doswell III, C. A.: An examination of jet stream configurations, $500 \mathrm{mb}$ vorticity advection patterns, and low-level thermal advection patterns during periods of intense convection, Mon. Weather Rev., 110, 184-197, 1982.

Miller, R. C.: Notes on analysis and severe storm forecasting procedures of the Air Force Global Weather Center, AWS Tech. Report 200 (Rev.), Headquarters Air Weather Service, Scott AFB, 106 pp., 1972.

Mlawer, E. J., Taubman, S. J., Brown, P. D., Iacono, M. J., and Clough, S. A.: Radiative transfer for inhomogeneous atmospheres: RRTM, a validated k-correlated model for the longwave, J. Geophys. Res., 102, 16663-16682, 1997.

Moore, J. T., Glass, F. H., Graves, C. E., Rochette, S. M., and Singer, M. J.: The Environment of Warm-Season Elevated Thunderstorms Associated with Heavy Rainfall over the Central United States, Weather Forecast., 18, 861-878, 2003.

Ramis, C., Romero, R., and Homar, V.: The severe thunderstorm of 4 October 2007 in Mallorca: an observational study, Nat. Hazards Earth Syst. Sci., 9, 1237-1245, doi:10.5194/nhess-9-12372009, 2009.

Showalter, A. K.: A stability index for thunderstorm forecasting, Bull. Amer. Meteor. Soc., 34, 240-252, 1953.

Whitman, C. D.: Mountain Meteorology, Oxford University Press, 2003. 